\title{
EXISTENCE AND BEHAVIOR OF SOLUTIONS FOR VARIATIONAL INEQUALITIES OVER PRODUCTS OF SETS
}

\author{
D. INOAN
}

Abstract. In this paper we study a variational inequality over a product of sets, governed by a multi-valued mapping, in pseudomonotonicity conditions. We are interested in the existence of the solution and, when the inequality depends on a parameter, also in the behavior of the solution at perturbations of the parameter.

Mathematics subject classification (2000): 47J20, 58E35, 49N60.

Keywords and phrases: parametric variational inequality over a product of sets; pseudomonotone setvalued mapping.

\section{REFERENCES}

[1] M. Ait Mansour And H. Riahi, Sensitivity Analysis for Abstract Equilibrium Problems, Journal of Mathematical Analysis and Applications, 306 (2005), 684-691.

[2] L. Q. ANH, AND P.Q. KHANH, Uniqueness and Hölder continuity of the solution to multivalued equilibrium problems in metric spaces, Journal of Global Optimization, 32 (2007), 449-465.

[3] Q.H. ANSARI AND Z. KHAN, Relatively B-pseudomonotone variational inequalities over product of sets, Journal of Inequalities in Pure and Applied Mathematics, 4, 1 (2003), article 6.

[4] M. Bogdan and J. Kolumbán, On Nonlinear Parametic Variational Inequalities, Nonlinear Analysis. Theory and Applications., 67, 7 (2007), 2272-2282.

[5] M. Bogdan And J. Kolumbán, Some regularities for parametric equilibrium problems, J. Glob. Optim. DOI 10.1007/s10898-008-9345-3, 2008.

[6] F.E. BRowDER AND P. HESs, Nonlinear mappings of monotone type in Banach spaces, in Journal of Functional Analysis, vol. 11 (1972), 251-294.

[7] H. BRÉZIS, Équations et inéquations non linéaires dans les espaces vectorieles en dualité, Ann. Inst. Fourier, 18 (1968), 115-175.

[8] H. Brézis, L. Nirenberg, and G. Stampacchia, A remark on Ky Fan's minimax principle, Boll. Unione Mat. Ital., 6 (1972), 293-300.

[9] C. COHEN AND F. Chaplais, Nested monotony for variational inequalities over product of spaces and convergence of iterative algorithms, J. Optim. Theory Appl., 59 (1988), 360-390.

[10] A. Doмокоs, Solution Sensitivity in Variational Inequalities, Journal of Mathematical Analysis and Applications, 230 (1999), 382-389.

[11] A. Domokos and J. Kolumban, Comparison of two different types of pseudomonotone mappings, Seminaire de la théorie de la meilleure approximation, convexite et optimisation, Cluj-Napoca (2000), 95-103.

[12] A.P. FARAJZADEH AND J. ZAFARANI, Equilibrium problems and variational inequalities in topological vector spaces, Optimization, DOI: 10.1080/02331930801951090, 2008.

[13] J. GWINNER, A note on pseudomonotone functions, regularization, and relaxed coerciveness, Nonlinear Anal., 30 (1997), 4217-4227.

[14] N. Hadjis avvas and S. Schaible, Generalized monotone maps, in N. Hadjisavvas, S. Komlósi and S. Schaible (eds), Handbook of Generalized Convexity and Generalized Monotonicity, Springer, 2005, pp. 389-420.

[15] S.H. Hu And N.S. PaPAGeORgiU, Handbook of Multivalued Analysis, vol. I, Kluver, 1997. 
[16] D. InOAn And J. Kolumbán, On pseudomonotone set-valued mappings, Nonlinear Analysis: Methods, Theory \& Applications, 68 (2008), 47-53.

[17] G. Kass AY, J. Kolumbán And Z. PÁLES, Factorization of Minty and Stampachia variational inequality system, European J. of Operational Research 143, pp. 377-389, 2002.

[18] P.Q. Khanh And L.M. LuU, Upper Semicontinuity of the Solution Set to Parametric Vector Quasivariational Inequalities, Journal of Global Optimization, 32 (2005), 569-580.

[19] S. KomLósi, Generalized Monontonicity in Nonsmooth Analysis, in Generalized Convexity, S. Komlòsi, T. Rapcsak and S. Schaible eds., 1994, pag. 263-275.

[20] I. KonNOv, Relatively monotone variational inequalities product sets, Oper. Res. Lett., 28 (2001), 21-26. 